\title{
The current threat level of fish in river network of individual sea-drainage areas in the Czech Republic
}

\author{
Stanislav Lusk, Bohumír Lojkásek, Lubomír Hanel, \\ Věra Lusková \& Petr Hartvich
}

Current threat level of fish in river network of individual sea-drainage areas in the Czech Republic. Acta Mus. Siles. Sci. Natur., 64: 251-261, 2015.

\begin{abstract}
The assessment of changes in the population spread of individual ichthyofauna species (lampreys and fishes) as well as the identification of unfavourable impacts is the necessary prerequisite for the correct selection of corrective measures. The river network in the Czech Republic belongs to the three sea-drainage areas (North Sea, Baltic Sea, and Black Sea). The species composition of the original ichthyofauna and the extent of the threat to some species differs in the individual sea-drainage areas. The original ichthyofauna in the Czech Republic consists of 4 lamprey species and 55 fish species. Out of this, only one lamprey species and 31 fish species originate in all three sea-drainage areas. There are 37 fish species considered as the original ones in the North Sea drainage area, there of 4 species are EX, 1 species EW, and 11 species $(29.7 \%)$ are threatened. In the Baltic Sea drainage area, there are 4 species EX, 1 species EW, and 8 species $(22.8 \%)$ threatened out of the total 35 assessed species. Out of 49 species in the Black Sea drainage area, there are 4 species EX and 23 species (46.9\%) threatened.

The most important reasons considered as the causes of the disappearance or reduction in the presence of some fishes are the water pollution, adjustments to water flow beds, the limitation of floods in alluvial areas, the permanent river basin fragmentation, and the spread of invasive species. Out of these factors, the only positive change has been noticed in the pronounced decrease in water flow pollution after 1990. Angling is also considered as the set of targeted bio manipulation which purposefully and often one-sidedly influences fish populations for the benefit of species being interesting for the angling sport.
\end{abstract}

Key words: sea-drainage area, native ichthyofauna, regional IUCN criteria, threatened species.

\section{Introduction}

The assessment of the situation and the extent of the threat to individual lampreys and fish species, considered as the original parts of the ichthyofauna in the Czech Republic, has been organised progressively after 1980. There have been a number of red lists assessing the threat to individual lamprey and fish species prepared in the course of more than 30 years. Originally, they were the lists valid for the complete river network of the three sea-drainage areas existing in Czechoslovakia (Baruš et al. 1981; Lusk 1989) and later in the Czech Republic (Lusk \& Hanel 1996; Hanel \& Lusk 2003; Lusk et al. 2004, 2011a). Most of the red lists assessed only the ichthyofauna species diversity and the extent of the threat to species. Lusk et al. (2002b) used the example of several species turning the attention to the absence of the protection of the interspecies diversity. Lusk et al. (1994) assessed the level of the threat to lampreys and fishes in 11 partial Czech river basins and Lusk (1996) did almost the same for the individual sea-drainage areas. Lojkásek \& Lusk (2001) assessed the extent of the threat to ichthyofauna in the River Odra basin in the Czech Republic.

The threat assessment and classification criteria for individual taxa were in the past used in time sequence in accordance with their specification by IUCN (1994, 2001, and 2010 respectively). The IUCN processes $(2001,2012 \mathrm{a})$ have focussed on the assessment of individual species within their spread areas and the regional variants (IUCN 2003, 2012b) on the use in smaller areas and hydrological systems. A number of authors have discussed the 
application of the IUCN instructions, e.g. Miller et al. (2007), Rodríguez (2008), and Rodríguez et al. (2015).

The set up of the regional ichthyofauna red list applicable for the three sea-drainage areas existing in the Czech Republic has required the use of some divergences of the general rules (IUCN 2012a) which have been therefore specified in details in the methodology part. We have also tried to indicate and react to some other problems related to the taxonomy and the angling management.

\section{Methodological comments}

The assessment of threat extent has been made for species considered as original in the river networks in the Czech Republic (Fig. 1) even if the occurrence of some of them was unique or accidental. In the total, there are 4 lamprey species and 55 fishes (Table 1). These species mostly appear on the lists of extinct species regionally. Specifically, they are Huso huso, Acipenser sturio, Coregonus oxyrinchus (taxonomic classification of the individual occurring accidentally once in our area is not clear), Rutilus virgo, and Platichthys flesus. The presence of Gymnocephalus baloni, Sander volgensis and Umbra krameri in the River Morava basin has been proved only in recent years and we might assume that they only passed unnoticed in the past (Lusk et al. 2000, 2002a). Proterorhinus semilunaris has been deleted from the list of original species (Lusk et al. 2011a).

When assessing the individual taxa, there were criteria by IUCN (2001) used - for the Czech version, see Plesník \& Cepáková (2005), taking into consideration the regional variant (IUCN 2003, 2012a). In the course of processing, there was the following difference utilised: "Assessed region - the river network of the relevant seadrainage area in the Czech Republic has been considered as a separated area". Thus, when classifying each occurrence (accidentally found individual, a part of the population), it was assessed with disregard to the current situation in the species population in the remaining area parts of the occurrence (river basin, sea-drainage area, or continent). Because of that, the assessment within the sea-drainage area has been stricter, in the case of some species, when comparing it within the countrywide assessment (Lusk et al. 2015) and, in the case of most species, stricter than within Europe (Freyhof \& Brooks 2011). The taxa have been classified into threatened categories using the following scale: Regional Extinct (EX), Extinct in the Wild (EW), Threatened - 1. Critically Endangered (CR), 2. Endangered (E), 3. Vulnerable (VU), Near Threatened (NT), and the Least Concern (LC).

\section{Area}

The surface water flow systems in the Czech Republic $\left(78864 \mathrm{~km}^{2}\right)$ in all sea-drainage areas (Fig. 1) have not been interconnected, with the exception of pirate transfers of small creeks in the source areas of River Sázava and River Jihlava (Brzák 1996) and River Bečva and River Odra during the historical times. From bio geographical point of view, it is interesting that the continental Saale glacier, in the course of last transgression, caused the pushing of the Upper River Odra to the South and the River Odra was thus, for a certain time, a tributary of the River Bečva, i.e. the part of the Black Sea drainage area (Kříž 1997). In the area of Šumava, there was the Schwarzenberg Channel built in the Middle Ages for wood floating. It even today connects the creeks in the watersheds of the North and the Black Seas.

The river networks of the three main rivers Labe, Odra and Morava have consisted, in the area of the Czech Republic, mostly of their source watershed areas. There were no obstacles in the individual watersheds in the past (till about the $15^{\text {th }}$ century) which would mean non passable barriers for fish. The original spread of individual species and the creation of fish populations were thus the result of natural development. Progressively, especially in the second half of the $19^{\text {th }}$ and in the course of the $20^{\text {th }}$ century, there were transverse constructions built which mean serious obstacles (weirs) or not passable barriers (dams) for the fish migration transfers along to the longitudinal profiles of water flows. The reservoir dams have divided watersheds of a number of water flows into not reversibly separated units (Lusk 1995; Lusk et al. 2014).

The biggest part of the area of the Czech Republic (65.2\%) belongs to the North Sea drainage area (the watershed of the River Labe). There has been the Vltava Cascade built on the River Vltava, the most important tributary of the River Labe - the nine reservoirs which have flooded the central part of the original bed of the River Vltava. From the ecological point of view, the ichthyocenoses in the upper watershed of the River Vltava, the watershed of the River Lužnice, the watershed of the River Otava and the watershed of the River Sázava have become separated. The water reservoir Nechranice also irreparably disturbed the continuity of the watershed of the River Ohře, the most important tributary in the lower part of the River Labe in the Czech Republic.

A small part of the Czech Republic (9.4\%) belongs to the Baltic Sea drainage area. Out of this, $78.6 \%$ makes up the watershed of the River Odra with its main tributaries of the River Opava, River Ostravice and River Olše in Northern Moravia. The rest is made up by not as important tributaries with sources in the Czech Republic and flowing into the River Odra in Poland (the Rivers Osoblaha, Bílá voda, Bělá, Vidnávka, Lužická Nisa, and Smědá). 
The area of the Czech Republic making up $25.4 \%$ belongs to the Black Sea drainage area. It is mostly the watershed of the River Morava and its most important tributary the River Dyje. Some smaller creeks in the Šumava region also belong to the Black Sea drainage area (the watersheds of Řezná u Železné Rudy, Malá Řezná u Medvědí hory, and the watersheds of Čertova voda and the Červený Creek. The same sea-drainage area relates to the flow Vlára and smaller creeks Drietomica, Klanečnica and Bošačka in the watershed of the River Váh in Slovakia. The system of water reservoirs in the watershed of the River Dyje has fragmented this hydrological complex into several ichthyologically separated parts (Lusk 1995). The watershed of the River Morava itself has been still relatively untouched (Lusk et al. 2014).

\section{Identity changes}

Taxonomic changes mean a problem which can complicate the assessment of the extent (level) of the threat to individual fish species and their legislative protection. This is mostly about the chance to utilise legislature when the species name was changed or the species was transferred into a different family, or when a single species was separated into more species. Specifically, this relates to the species Sabanejewia aurata (Filippi, 1865), now correctly Sabanejewia balcanica (Karaman, 1922). The genetic analyses resulted in the situation in which the genus Romanogobio, covering the two following species with the changed species identity, has been separated from the genus Gobio. Romanogobio albipinnatus (Lukasch, 1933) in the watershed of the River Morava is now called Romanogobio vladykovi (Fang, 1943). Beside this, another species has been recently found in the lower part of the River Labe - Romanogobio belingi (Slastenenko, 1934), the originality of which in the watershed of the River Labe is accompanied with some doubts (Lusk et al. 2005). Similarly, the species Romanogobio kesslerii (Dybowski, 1862) has changed its identity from the scientific name point of view to Romanogobio banaticus (Banarescu, 1960), Mendel et al. (2008a, 2008b). Changes in the genus names have been noticed also in some other species. The original Leuciscus cephalus is now called Squalius cephalus and similarly, instead of the genus Abramis, the species Ballerus ballerus and Ballerus sapa carry the name of a different genus.

The future situation will be probably complicated also by the revelation, acknowledgement respectively of the so-called "cryptic" species as the new independent taxa. The question remains which genetic population difference, within the existing species, will be considered as the interspecies diversity and when we will consider it as the difference between species. As an example, we can present the results of genetic analyses of Cottus poecilopus, where the populations from the watershed of the River Odra have been clearly differentiated and marked as the complex baltica and the population from the watershed of the River Dunaj (Morava, Ida) was marked as the complex danubialis (Lusk et al. 2008b).

The materials for the preparation of this red list version of lampreys and fishes in the Czech Republic have been mostly the authors' knowledge of the situation and the population development in the individual species in the course of the last 20 years, while considering the newest bibliographic data.

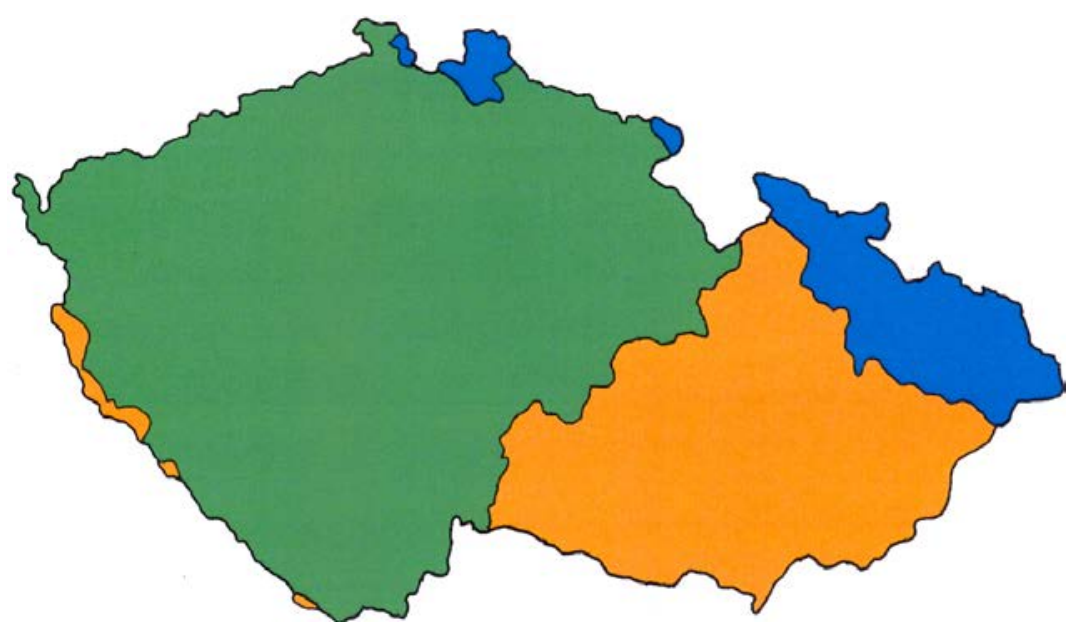

Fig 1: Czech Republic land affiliation to sea-drainage areas of the North Sea (green), Baltic Sea (blue) and Black Sea (ochre). 


\section{Results}

Ichthyofauna of the Czech Republic, according to the current assessment, consists of 4 original lamprey species and 55 original fish species (Tab. 1). Out of this, we consider as currently extinct 2 lamprey species and 7 fish species (Lusk et al. 2015). There are differences in the number of existing species as well as in the extent of the threat related to them in river systems of the individual sea-drainage areas. A substantial part of the taxa, specifically 1 lamprey species and 31 fish species, occur in all three sea-drainage areas. The occurrence of 2 lamprey species and 20 fish species is specific only for a single sea-drainage area. One lamprey species and 4 fish species are specific only for two sea-drainage areas.

Tab 1: Species composition of the ichthyofauna in the Czech Republic by sea-drainage area and the extent of threat to individual species.

\begin{tabular}{|c|c|c|c|c|c|}
\hline Family / Species & ČR 2010 & $\check{C}$ ČR 2015 & Black Sea & Baltic Sea & North Sea \\
\hline \multicolumn{6}{|l|}{ Petromyzontidae } \\
\hline Petromyzon marinus Linnaeus, 1758 & EX & EX & 0 & 0 & $+\mathrm{EX}$ \\
\hline Eudontomyzon mariae (Berg, 1931) & $\mathrm{CE}$ & $\mathrm{CE}$ & $+\mathrm{CE}$ & 0 & 0 \\
\hline Lampetra planeri (Bloch, 1784) & EN & EN & $+\mathrm{EN}$ & $+\mathrm{EN}$ & $+\mathrm{VU}$ \\
\hline Lampetra fluviatilis (Linnaeus, 1758) & EX & EX & 0 & $+\mathrm{EX}$ & $+\mathrm{EX}$ \\
\hline \multicolumn{6}{|l|}{ Acipenseridae } \\
\hline Huso huso (Linnaeus, 1758) & $\overline{E X}$ & $\overline{E X}$ & $+\mathrm{EX}$ & 0 & 0 \\
\hline Acipenser ruthenus (Linnaeus, 1758) & $\overline{\mathrm{CR}}$ & $\mathrm{CR}$ & $+\mathrm{CR}$ & 0 & 0 \\
\hline Acipenser sturio Linnaeus, 1758 & EX & EX & 0 & $+\mathrm{EX}$ & $+\mathrm{EX}$ \\
\hline \multicolumn{6}{|l|}{ Anguillidae } \\
\hline 2) Anguilla anguilla (Linnaeus, 1758) & NT & EW & 0 & $+\mathrm{EW}$ & $+\mathrm{EW}$ \\
\hline \multicolumn{6}{|l|}{ Clupeidae } \\
\hline Alosa alosa (Linnaeus, 1758) & EX & EX & 0 & 0 & $+\mathrm{EX}$ \\
\hline \multicolumn{6}{|l|}{ Cyprinidae } \\
\hline Rutilus rutilus (Linnaeus, 1758) & $\mathrm{LC}$ & $\mathrm{LC}$ & $+\mathrm{LC}$ & $+\mathrm{LC}$ & $+\mathrm{LC}$ \\
\hline Rutilus virgo (Heckel 1852) & EX & EX & $+\mathrm{EX}$ & 0 & 0 \\
\hline Leuciscus leuciscus (Linnaeus, 1758) & $\overline{\mathrm{LC}}$ & $\overline{\mathrm{LC}}$ & $+\mathrm{LC}$ & $+\mathrm{LC}$ & $+\mathrm{LC}$ \\
\hline Squalius cephalus (Linnaeus, 1758) & $\overline{\mathrm{LC}}$ & $\mathrm{LC}$ & $+\mathrm{LC}$ & $+\mathrm{LC}$ & $+\mathrm{LC}$ \\
\hline Leuciscus idus (Linnaeus, 1758) & NT & NT & $+\mathrm{NT}$ & $+\mathrm{NT}$ & $+\mathrm{NT}$ \\
\hline Phoxinus phoxinus (Linnaeus, 1758) & $\mathrm{VU}$ & $\mathrm{VU}$ & $+\mathrm{VU}$ & $+\mathrm{NT}$ & $+\mathrm{VU}$ \\
\hline Scardinius erythrophthalmus (Linnaeus, 1758) & $\mathrm{LC}$ & $\mathrm{LC}$ & $+\mathrm{LC}$ & $+\mathrm{LC}$ & $+\mathrm{LC}$ \\
\hline Aspius aspius (Linnaeus, 1758) & $\mathrm{LC}$ & $\mathrm{LC}$ & $+\mathrm{LC}$ & $+\mathrm{LC}$ & $+\mathrm{LC}$ \\
\hline Leucaspius delineatus (Heckel, 1843) & $\mathrm{CR}$ & $\mathrm{CR}$ & $+\mathrm{CR}$ & $+\mathrm{CR}$ & $+\mathrm{CR}$ \\
\hline Tinca tinca (Linnaeus, 1758) & $\overline{\mathrm{LC}}$ & EN & $+\mathrm{EN}$ & $+\mathrm{EN}$ & $+\mathrm{EN}$ \\
\hline Chondrostoma nasus (Linnaeus, 1758) & VU & $\mathrm{VU}$ & $+\mathrm{VU}$ & $+\mathrm{VU}$ & 0 \\
\hline Gobio gobio (Linnaeus, 1758) & $\overline{\mathrm{LC}}$ & LC & $+\mathrm{LC}$ & $+\mathrm{LC}$ & $+\mathrm{LC}$ \\
\hline${ }^{3)}$ Romanogobio banaticus (Banarescu, 1960) & $\mathrm{CR}$ & $\mathrm{CR}$ & $+\mathrm{CR}$ & 0 & 0 \\
\hline${ }^{3)}$ Romanogobio vladykovi (Fang, 1943) & VU & VU & $+\mathrm{VU}$ & 0 & 0 \\
\hline Barbus barbus (Linnaeus, 1758) & NT & NT & $+\mathrm{LC}$ & $+\mathrm{NT}$ & $+\mathrm{LC}$ \\
\hline Alburnus alburnus (Linnaeus, 1758) & $\overline{\mathrm{LC}}$ & $\mathrm{LC}$ & $+\mathrm{LC}$ & $+\mathrm{LC}$ & $+\mathrm{LC}$ \\
\hline Alburnoides bipunctatus (Bloch, 1782) & $\overline{E N}$ & $\mathrm{VU}$ & $+\mathrm{VU}$ & $+\mathrm{VU}$ & $+\mathrm{VU}$ \\
\hline Abramis bjoerkna (Linnaeus, 1758) & $\overline{\mathrm{LC}}$ & LC & $+\mathrm{LC}$ & $+\mathrm{LC}$ & $+\mathrm{LC}$ \\
\hline Abramis brama (Linnaeus, 1758) & LC & $\mathrm{LC}$ & $+\mathrm{LC}$ & $+\mathrm{LC}$ & $+\mathrm{LC}$ \\
\hline Ballerus sapa (Pallas, 1814) & $\mathrm{CR}$ & CR & $+\mathrm{CR}$ & 0 & 0 \\
\hline Ballerus ballerus (Linnaeus, 1758) & $\mathrm{VU}$ & $\mathrm{VU}$ & $+\mathrm{VU}$ & 0 & $+\mathrm{CR}$ \\
\hline Vimba vimba (Linnaeus, 1758) & $\mathrm{VU}$ & $\mathrm{VU}$ & EN & $+\mathrm{EX}$ & $+\mathrm{VU}$ \\
\hline Pelecus cultratus (Linnaeus, 1758) & $\overline{C R}$ & $\mathrm{CR}$ & $+\mathrm{CR}$ & 0 & 0 \\
\hline Rhodeus amarus (Bloch, 1782) & EN & $\mathrm{VU}$ & $+\mathrm{VU}$ & $+\mathrm{VU}$ & $+\mathrm{VU}$ \\
\hline Carassius carassius (Linnaeus, 1758) & $\mathrm{CR}$ & $\mathrm{CR}$ & $+\mathrm{CR}$ & $+\mathrm{CR}$ & $+\mathrm{CR} ? ?$ \\
\hline Cyprinus carpio Linnaeus, 1758 & EX & EX & $+\mathrm{EX}$ & 0 & 0 \\
\hline
\end{tabular}




\begin{tabular}{|c|c|c|c|c|c|}
\hline Family / Species & ČR 2010 & $\check{\text { ČR } 2015}$ & Black Sea & Baltic Sea & North Sea \\
\hline \multicolumn{6}{|l|}{ Cobitidae } \\
\hline Cobitis elongatoides Bacescu et Maier, 1969 & $\overline{\mathrm{EN}}$ & $\overline{\mathrm{EN}}$ & $+\mathrm{EN}$ & $+\mathrm{EX}$ & $+\mathrm{EN}$ \\
\hline 4) Sabanejewia balcanica (Karaman, 1922) & $\mathrm{CR}$ & $\mathrm{CR}$ & $+\mathrm{CR}$ & 0 & 0 \\
\hline Misgurnus fossilis (Linnaeus, 1758) & EN & EN & $+\mathrm{EN}$ & $+\mathrm{EN}$ & $+\mathrm{VU}$. \\
\hline \multicolumn{6}{|l|}{ Balitoridae } \\
\hline Barbatula barbatula (Linnaeus, 1758) & $\overline{\mathrm{LC}}$ & $\overline{\mathrm{LC}}$ & $+\mathrm{LC}$ & $+\mathrm{LC}$ & $+\mathrm{LC}$ \\
\hline \multicolumn{6}{|l|}{ Siluridae } \\
\hline Silurus glanis Linnaeus, 1758 & $\overline{\mathrm{LC}}$ & $\overline{\mathrm{LC}}$ & $+\mathrm{LC}$ & $+\mathrm{LC}$ & $+\mathrm{LC}$ \\
\hline \multicolumn{6}{|l|}{ Esocidae } \\
\hline Esox lucius Linnaeus, 1758 & $\mathrm{LC}$ & $\overline{\mathrm{LC}}$ & $+\mathrm{LC}$ & $+\mathrm{LC}$ & $+\mathrm{LC}$ \\
\hline \multicolumn{6}{|l|}{ Umbridae } \\
\hline${ }^{5)}$ Umbra krameri Walbaum, 1792 & & $\mathrm{CR}$ & $+\mathrm{CR}$ & 0 & 0 \\
\hline \multicolumn{6}{|l|}{ Salmonidae } \\
\hline Salmo salar Linnaeus, 1758 & $\mathrm{CR}$ & CR & 0 & $+\mathrm{EX}$ & $+\mathrm{CR}$ \\
\hline Salmo trutta Linnaeus, 1758 & LC & $\overline{\mathrm{LC}}$ & $+\mathrm{LC}$ & $+\mathrm{NT}$ & $+\mathrm{LC}$ \\
\hline Hucho hucho (Linnaeus, 1758) & EW & EX & $+\mathrm{EX}$ & 0 & 0 \\
\hline Coregonus oxyrinchus (Linnaeus, 1758) & EX & EX & 0 & 0 & $+\mathrm{EX}$ \\
\hline Thymallus thymallus (Linnaeus, 1758) & NT & $\mathrm{VU}$ & $+\mathrm{VU}$ & $+\mathrm{VU}$ & + NT \\
\hline \multicolumn{6}{|l|}{ Lotidae } \\
\hline Lota lota (Linnaeus, 1758) & NT & NT & $+\mathrm{NT}$ & $+\mathrm{NT}$ & $+\mathrm{NT}$ \\
\hline \multicolumn{6}{|l|}{ Cottidae } \\
\hline Cottus gobio Linnaeus, 1758 & $\mathrm{VU}$ & NT & $+\mathrm{NT}$ & $+\mathrm{NT}$ & $+\mathrm{NT}$ \\
\hline Cottus poecilopus Heckel, 1837 & NT & NT & $+\mathrm{NT}$ & $+\mathrm{NT}$ & 0 \\
\hline \multicolumn{6}{|l|}{ Percidae } \\
\hline Sander lucioperca (Linnaeus, 1758) & $\mathrm{LC}$ & $\mathrm{LC}$ & $+\mathrm{LC}$ & $+\mathrm{LC}$ & $+\mathrm{LC}$ \\
\hline Sander volgensis (Gmelin, 1789) & NT & NT & $+\mathrm{NT}$ & 0 & 0 \\
\hline Perca fluviatilis Linnaeus, 1758 & $\mathrm{LC}$ & $\mathrm{LC}$ & $+\mathrm{LC}$ & $+\mathrm{LC}$ & $+\mathrm{LC}$ \\
\hline Zingel zingel (Linnaeus, 1758) & $\mathrm{CR}$ & $\mathrm{CR}$ & $+\mathrm{CR}$ & 0 & 0 \\
\hline Zingel streber (Siebold, 1863) & $\mathrm{CR}$ & $\mathrm{CR}$ & $+\mathrm{CR}$ & 0 & 0 \\
\hline Gymnосерhalus cernua (Linnaeus, 1758) & LC & $\mathrm{LC}$ & $+\mathrm{LC}$ & $+\mathrm{LC}$ & $+\mathrm{LC}$ \\
\hline Gymnосерhalus schraetser (Linnaeus, 1758) & CR & CR & $+\mathrm{CR}$ & 0 & 0 \\
\hline Gyтnосерhalus baloni Holčík et Hensel, 1974 & CE & CR & $+\mathrm{CR}$ & 0 & 0 \\
\hline \multicolumn{6}{|l|}{ Pleuronectidae } \\
\hline Platichthys flesus Linnaeus, 1758 & EX & EX & 0 & 0 & $+\mathrm{EX}$ \\
\hline
\end{tabular}

\section{Key}

+ Original in the sea drainage area, 0 - Not original in the sea drainage area, ČR 2010 - Red list of Czech Republic, Version 2010, ČR 2015 - Red list of Czech Republic, Version 2015 (the new one)

1) Acipenser ruthenus was, even in the past, a rare guest in the Rivers Morava and Dyje. There were two individuals caught in 1977 and their total lengths were $55 \mathrm{~cm}$ and $68 \mathrm{~cm}$ in the River Dyje (River Km 26.7) below the weir in Břeclav. Both fish were released back into the river by the anglers after they took the measurements. There is the information, from the period $1992-1998$, about unique catches of A. ruthenus of the weight about 0.5-1.0Kg. They were always released back into the water (Lusk et al. 2000, 2002a). In May 2008, one fish of this species was caught below the weir in Břeclav (M. Horáček - Findings database of the nature protection, Agency for Nature Conservation and Landscape Protection of the Czech Republic). Considering fingerlings of this species put into waters in the Slovak part of the River Morava in recent years, we may expect casual occurrence of this species in the confluence area.

2) Anguilla anguilla is currently put into waters of the River Labe, into a part of the River Vltava watershed and into the River Odra watershed, where the adult migration is not made impossible by dams, as "monté". In other parts of the hydrological system of the Czech Republic, including the river Morava watershed, where A. anguilla is not the original species, there are only old individuals remaining from the times when the eel monté was introduced across the board.

3) The genetic analyses done recently have resulted in new knowledge about the species affiliation of the populations of the genus Romanogobio in Czech waters. The population in the watersheds of the Rivers Morava and Dyje, considered originally as (Gobio) Romanogobio albipinnatus, are currently called as Romanogobio vladykovi (Fang, 1943). The population occurring in the lower flow of the River Labe belongs to the taxon Romanogobio belingi (Slastenenko, 1934). However, there are some doubts about the origin of this species in the watershed. Romanogobio kesslerii (Dybowski, 1862) in the watershed of the River Morava has been considered, especially considering the genetic differences, as Romanogobio banaticus (Banarescu, 1960), Mendel et al. (2008a, 2008b).

4) Sabanejewia balcanica was originally occurring in the watershed of the River Bečva (the watershed of the River Morava), where it has disappeared in the last century. The existence of this species was found in the flow of Vlára (the watershed of the River Váh), close to the Slovak borders, in 2001 (Lusk et al. 2002c).

5) The occurrence of Umbra krameri is known in the River Morava watershed in Slovakia very close to the confluence of the Rivers Morava and Dyje (Hajdů et al. 2008). We may expect, following the information from anglers, that the species occurred also in the Czech Republic, in the area of Hodonín, in the period of WWI. In 2007, there were several tens of individuals caught during rescue catching and they were introduced into the River Dyje watershed near Lednice (Lusk 2010). In 2014, there was the local population found and the occurrence was confirmed also in 2015 . 


\section{North Sea drainage area}

Originally, there were 3 lamprey species in the River Labe watershed. The species Petromyzon marinus and Lampetra fluviatilis migrated there from the sea environment for their reproduction. Both species are currently considered as EX. Considering the current abundant occurrence of both anadromous species in the lower part of the River Labe in Germany (Adam et al. 2012), it is expected that the occurrence of P. marinus and L. fluviatilis will be confirmed again in the River Labe in the Czech Republic in near future. Lampetra planeri is relatively wide spread in the whole River Labe system and its current assessment is VU.

There are 37 fish species considered as original in the River Labe watershed. Out of this, 6 species are diadromous as they switch between the sea and the fresh water environments. They are Salmo salar, Anguilla anguilla and rarely in the past found A. sturio, A. alosa, C. oxyrinchus and P. flesus. the last 4 named species are considered as EX. The specific taxon is Salmo trutta m. trutta, which is also considered as extinct, but its unique and rare occurrence in the Czech part of the River Labe cannot be dismissed (Vostradovský \& Šmíd 1999). From among the mentioned diadromous taxa, there has been the occurrence of $S$. salar so far successfully renewed at least partly in the River Labe watershed in the Czech Republic. Andreska \& Hanel (2015) have analysed the reasons behind its disappearance from the River Labe. There were 4 million fingerlings put into the watersheds of the Rivers Ploučnice, Ohře and Kamenice in the period 1995 - 2015. Only about 80 adults have been registered in the period (catches, found dead individuals, and observed individuals). The first spawning places and the assumed spawning were observed in 2002 (Kava 2007, 2015). Even if the return of $S$. salar has been confirmed, it has not been so far naturally reproducing and stabile population. Also, the more numerous occurrences of $A$. anguilla have been maintained only by the continuous imports and insertion of juvenile individuals (monté) (MŽP 2007).

Out of the total number of 37 occurring fish species, 4 species are assessed as EX, 1 species (A. anguilla) as EW, 11 species as threatened (CE, E, VU), and 21 species not threatened (NT or LC), for more details see Table 1.

\section{Baltic Sea drainage area}

There are 2 lamprey species and 35 fish species original in the Baltic Sea drainage area of the Czech Republic. Out of the mentioned 2 lamprey species, the diadromous L. fluviatilis has been EX for a number of years. Out of 35 fish species, 4 species are EX (the diadromous A. sturio and S. salar, Cobitis elongatoides and Vimba vimba). A. anguilla is assessed as EW. Eight species are threatened (CR, E, or VU) and the total of 22 species are not endangered (NT, LC), for more details see Table 1.

Considering the existence of the high number of migration obstacles in the Polish part of the River Odra, the natural renewal of the occurrence of L. fluviatilis, S. salar and A. anguilla in the area of the Czech Republic might be possible only after their migration passage becomes free and after the organised repatriation. The occurrence of $A$. sturio in the lower part of the River Odra has not been recorded for a long time and its renewal is unrealistic even in distant future (Mamcarz 2000).

\section{Black Sea drainage area}

There have been 2 lamprey species and 49 fish species assessed as original in the Black Sea drainage area. Eudontomyzon mariae currently occurs only in one locality in the Czech Republic and it is critically threatened there (Lusk et al. 2008; Merta 2008; Hanel et al. 2015). The noticeably higher number of fish species, when comparing it with the previous two seadrainage areas, has been caused by the occurrence of 15 taxa, which originate exclusively in 
the River Dunaj watershed, in the Black Sea drainage area in the Czech Republic respectively - see Table 1. Four species are considered as EX (Huso huso, Rutilus virgo, Cyprinus carpio the original form Hucho hucho). Twenty-three species have been assessed as threatened at various extents (CR, EN, and VU). This is practically a half of the occurring species. The total of 22 species has been assigned to the category indicating the minimal level of the threat (NT, LC), see Table 1 .

\section{Discussion}

The fact that some species are managed for angling means an important problem when assessing their spread and population quantitative parameters. The species which make the objects of production fish farming (C. carpio, Tinca tinca, Esox lucius, Sander lucioperca, Silurus glanis), are regularly put into free flows for angling purposes. Salmo trutta and Thymallus thymallus, the two important species of salmon-relevant flows, have been artificially reproduced and consequently released into angling areas since the second half of the $19^{\text {th }}$ century (Frič $\left.1872,1875,1876,1908\right)$. The artificial reproduction and fingerling releases of other species started in the last third of the $20^{\text {th }}$ century (Chondrostoma nasus, Aspius aspius, S. cephalus, Leuciscus idus, Barbus barbus, V. vimba, Lota lota) for the purpose of increasing the numbers of their populations in flows (Hanel \& Lusk 2005). Some limited numbers of species (Phoxinus phoxinus, Misgurnus fosilis) were transferred with the aim to renew their occurrence or to strengthen the numbers in the existing populations (Dušek 2003; Hartvich \& Šperl 2011). These biomanipulative activities within the fish management, in most water flows in the Czech Republic, make the assessment of spread changes and of the numbers of affected species populations almost impossible.

The scope of negative effects of unfavourable impacts (the pollution, adjustments to water flow beds, hydro-technological constructions, transformations of the natural water flow rates, etc.) on individual species and the whole fish populations progressively increased during the $19^{\text {th }}$ and especially in the $20^{\text {th }}$ century. The influences of the most mentioned factors are mostly of the permanent character. The reduction or elimination of these impacts on the situation in ichthyocenoses is considered as the necessary prerequisite for their development towards the natural state.

It has been proved (Cenia 2010; Volaufová 2008) that out of the mentioned negative factors, only the water pollution was, even if for a relatively short time, clearly improved at the end of the $20^{\text {th }}$ and the start of the $21^{\text {st }}$ century. An important decrease in the amount of released pollutants from point sources was noticed in the Czech Republic in the period 19932010. The basic indicators present the reduction by $93 \%$ BSK $5,86 \%$ CHSKCr and $89 \%$ of not dissolved substances. The most important amount reduction in released pollutants took place in the 1990s. That was mainly the result of restructuring and modernising of agricultural and industrial operations and the extensive construction or upgrading of large waste water treatment plants. These facts were the reasons behind the renewal of the original fish populations proved, for example, in lower parts of the water flows of the Rivers Odra, Olše (Lojkásek \& Lusk 2006), Morava, and Dyje (Lusk \& Holčík 1998; Lusk et al. 2000, 2002a).

Since 2003, the amounts of released pollutants report only a slow reduction.

The positive trend in the reduction of released pollutants stopped in 2010 and, when compared with the year 2009, the amount of released pollutants slightly increased year-onyear in all monitored indicators.

The migration impenetrability of river systems has not significantly changed so far. The reservoir dams practically permanently and irreversibly separate individual parts of river networks, especially the Rivers Vltava and Dyje watersheds. After 2000, there have been the longitudinal migration passages locally renewed through flow beds in some profiles which were formerly not passable thanks to various river objects (Lusk et al. 2014). However, there 
are clear proofs still missing about the effectiveness of these activities. It shows that the only problem is not the impassable migration objects, but also the extended weir reservoirs. They have the length of several kilometres in larger rivers and that completely changes the original river character of the affected water flow bed from the hydrological, hydraulic and biological points of view. For example, there are 16 impassable steps on the River Morava, in the section between the river kilometres 70 and 233.6 and the weir reservoirs cover $57 \%$ of the longitudinal profile of this river bed part. The conceptual renewal of migration penetrability of the river systems in the Czech Republic (Slavíková et al. 2009) has been, so far, in the introductory stage of implementation and its effect might be expected probably only in future years.

The spread of not original invasive fish species is a negative factor affecting the original fish populations (Lusk et al. 2010). The now utilised legislative process (Act No. 114/1992 Coll.) is to the detriment of the non original species and their natural reproduction is thus almost impossible (Oncorhynchus mykiss, Ctenopharyngodon idella) or strongly limited (Salvelinus fontinalis). In opposite, the legislature does not influence the handling of typical invasive species (Carassius gibelio, Pseudorasbora parva), see Lusk et al. (2011b); Pokorná (2011).

There are many revitalising activities currently taking place in the Czech Republic within the regional plans. However, they cover mostly small water flows (Just et al. 2005; Jakoubková 2012; Birklen \& Jarošek 2014) or returns to natural state related to extreme floods like, for example, in River Bečva (Lusk et al. 2003; Klečka 2005). The measures correcting mistakes made by adjustments of the longitudinal or the cross profiles of larger water flow beds have not been considered in the Czech Republic so far. Also, the renewal of functional flooded areas, which have been separated in the past from their main flows by dams against floods, has been mostly unrealistic thanks to the currently existing constructions and the eco system changes.

It shows that the assessment of individual impacts on the spread and on the quantitative parameters of individual species populations should become a part of the assessment of the extent of the threat to the individual species. It is just the knowledge of the decisive factors, within the time scope of the red lists' updates, which could allow for the more precise prediction of the development in populations of individual species and, consequently, for the acceptance of relevant corrective measures. From this point of view, the application of this approach seems more suitable for the ichthyofauna in smaller land areas like the river basin or its part.

\section{References}

Adam B., Faller M., Gischkat S., Hufgard H., Lowenberg S. \& Mast N. (2012): Ergebnisse nach einem Jahrfischökologischen Monitorings am Doppelschlitzpass Geesthacht. - Wasser Wirtschaft 102 (4): 49-57.

Andreska J. \& Hanel L. (2015): Historical occurrence and extinction of Atlantic salmon in the River Elbe from the fourteenth to the twentieth centuries. - Arch. Pol. Fish. 23: 3-16.

Baruš V., Lusk S. \& Gajdůšek J. (1981): Fauna ryb a její zachování v Československu. - Památky a př́roda, 1981(10): 619-623.

Birklen P. \& Jarošek R. (2014): Revitalizace Bílovky v CHKO Poodří. - Ochrana přírody 2014(5): 20-23.

Brito D., Ambal R.G., Brooks T. et al. (2010): How similar are national red lists and the IUCN red list? Biological Conservation 143: 1154-1158.

Brzák M. (1996): Vybrané problémy říční sítě v povodí Jihlavy. - Acta Mus. Moraviae, Sci.Nat., LXXXI (1/2): 109-120.

CENIA (2010): Zpráva o životním prostředí 2010. Available in http://www.cenia.cz.

Dušek J. (2003): Metodická př́ručka pro ochranu populací, chov a repatriaci střevle potoční s poznámkami o biologii druhu. Agentura ochrany př́rody a krajina ČR, 44 pp.

Freyhof J. \& Brooks E. (2011): European Red list of freswater fishes. Luxembourg: Publication Office of the European Union, $72 \mathrm{pp}$. 
Frič A. (1872): O rybářství v řekách českých a o jeho poměru k umělému pěstování ryb a k průmyslu. - Archiv př́rodovědecký k proskoumání Čech, II d. 4: 149-188.

- (1875): Umělé pěstování ryb v Čechách. V komisi Fr. Řivnáče v Praze, nákl. vlastním, 36 pp.

- (1876): Zpráva o chovu lososů a pstruhů v Čechách v r. 1874-1875. - Vesmír 5(14): 165-166; 5(16): 186-188.

- (1908): České ryby a jich cizopasníci. Nákl. vlastním, Praha, 80 pp.

Hajdú J., Koščo J., Pekárik L., Lusková V., Lusk S., Valachovič D. \& Tomeček J. (2008): Blatniak tmavý (Umbra krameri): súčasný stav a perspektívy. Sb. XI. Česká ichtyologická konference, MZLU Brno: $67-71$.

Hanel L., Andreska J., Drozd B., Hartvich P. \& Lusk S. (2015): Biologie a ochrana mihulí. Fakulta rybářství a ochrany vod Jihočeské univerzity, Vodňany, 551 pp.

Hanel L. \& Lusk S. (2003): Červený seznam mihulí a ryb České republiky. - Př́roda, Praha 22: 73-82.

- (2005): Ryby a mihule České republiky - rozšíření a ochrana. ČSOP Vlašim, 447 pp.

Hartvich P. \& Šperl J. (2011): Odchov střevle potoční (Phoxinus phoxinus L.) v př́rodních podmínkách pro vodní toky v Národním parku Šumava. Metodická publikace FROV JU České Budějovice, 26 pp.

IUCN (1994): IUCN Red List Categories and Criteria. Prepared by the IUCN Species Survival Commission. As approved by the 40th Meeting of the IUCN Council, Gland, Switzerland, 30 November 1994. IUCN, Gland, Switzerland and Cambridge, UK.

- (2001): IUCN Red List Categories and Criteria: Version 3.1. IUCN Species Survival Commision. IUCN, Gland, Switzerland and Cambridge, UK, $21 \mathrm{pp}$.

- (2003): Guidelines for application of IUCN Red list Criteria at regional levels: Version 3.0. IUCN Species Survival Commission.- IUCN, Gland, Switzerland and Cambridge, UK.ii +26 pp.

- (2010): IUCN Standards and Petitions Subcommittee. 2010. Guidelines for Using the IUCN Red List Categories and Criteria. Version 8.1. Prepared by the Standards and Petitions Subcommittee in March 2010. Downloadable from http://intranet.iucn.org/webfiles/doc/SSC/RedList/RedListGuidelines.pdf.

- (2012a): IUCN Red List Categories and Criteria: Version 3.1. Second edition. Gland, Switzerland and Cambridge, UK, 38 pp.

- (2012b): Guidelines for application of IUCN Red list criteria at region and national levels. Versio 4.0. Gland, Switzerland and Cambridge, UK, $41 \mathrm{pp}$.

Jakoubková R. (2012): Revitalizace v údolí Divoké Orlice. - Orlické hory a Podorlicko 19: 267-275.

Just T., Matoušek V., Dušek M., Fischer D. \& Karlík P. (2005): Vodohospodářské revitalizace a jejich uplatnění v ochraně před povodněmi. ZO ČSOP Hořovicko, 359 pp.

Kava T. (2007): Průběh repatriace lososa obecného v ČR a perspektivy jejího dalšího postupu. Semináŕ „Losos 2007“, Ústí n.Labem, 11 pp.

- (2015): Repatriace lososa obecného v povodí Labe na území ČR 2012-2015. Zpráva - ms., 41 pp.

Klečka J. (2005): Spojená Bečva po povodních 97-příklad spontánního vývoje toku. Sb. Řiční krajina 3, Olomouc, pp. 155-162.

Kottelat M. \& Freyhof J. (2007): Handbook of European freshwater fishes. Kottelat Cornol Switzerland and Freyhof, Berlin, Germany, 646 pp.

Kříž V. (1997): Fyzickogeografická charakteristika povodí horního toku Odry na území Č. republiky. - Acta Fac. Rer. Nat. Univ. Ostraviensis, Geografica - Geologica 5: 7-16.

Lojkásek B. \& Lusk S. (2001): Ohrožené a bioindikačně významné druhy mihulovců a ryb v povodí řeky Odry na území Moravy a Slezska. - Acta Fac. Rer. Nat. Univ. Ostraviensis, Biologica - Ecologica 8: 133140.

- (2006): Ichtyofauna povodí Odry - př́íčiny a perspektivy. - Scripta Facultatis Rerum Naturalium Universitatis Ostraviensis Nr. 163. Environmental changes and biological assessment III., pp. 230-234.

Lusk S. (1989): Gene pool of fishes in Czechoslovakia: present state and conservation efforts. Práce VÚRH Vodňany 18: 15-26.

- (1995): Influence of valley dams on the changes in fish communities inhabiting streams in the Dyje river drainage area. - Folia Zool. 44: 45-56.

- (1996): The status of the fish fauna in the Czech Republic. In: Kirchhofer A. \& Hefti D. (eds): Conservation of endangered freshwater fish in Europe. Birkhäuser Verlag Basel/Switzerland, pp. 89-98.

- (2010): Jak je to s blatňákem tmavým na jižní Moravě? - Živa 2010, č. 3, Forum, L: 1 s.

Lusk S., Bartoňová E., Lusková V., Lojkásek B. \& Koščo J. (2008a): Vranka pruhoploutvá Cottus poecilopus - rozšíření a genetická diverzita v povodí řek Morava, Odra (Česká republika) a Hornád (Slovensko). - Biodiverzita ichtyofauny ČR (VII): 67-80.

Lusk S., Halačka K., Lusková V. \& Horák V. (2005): Distribution of Gobio species in the Czech Republic. - Folia Zool. 54 (Suppl.) 1: 56-64.

Lusk S. \& Hanel L. (1996): Červený seznam mihulí a ryb České republiky - verze 1995. - Biodiverzita ichtyofauny ČR (I): 16-25. 
Lusk S., Hanel L. \& Křesina J. (2008b): Je zánik populace mihule ukrajinské Eudontomyzon mariae v Račím potoce neodvratný? - Biodiverzita ichtyofauny ČR (VII): 6-16.

Lusk S., Hanel L., Lojkásek B., Lusková V. \& Muška M. (2015): Červený seznam mihulí a ryb České republiky - ms., verze 2015.

Lusk S., Hanel L. \& Lusková V. (2004): Red List of the ichthyofauna of the Czech Republic: Development and present status. - Folia Zool. 53: 215-226.

Lusk S., Hartvich P. \& Lojkásek B. (2014): Migrace ryb a migrační prostupnost vodních toků FROV JU, Vodňany, $254 \mathrm{pp}$.

Lusk S. \& Holčík J. (1998): Význam bezbariérového spojení říčního systému Moravy a Dyje na: území České republiky s Dunajem. Biodiverzita ichtyofauny ČR (II): 69-83.

Lusk S., Lohniský K. \& Vostradovský J. (1994): Červený seznam mihulí a ryb České republiky. Sborník referátů z ichtyologické konference, Vodňany: 187-193.

Lusk S., Lojkásek B., Halačka K. \& Lusková V. (2003): „Povodňové“ revitalizace na Rožnovské Bečvě. Bull. Lampetra V, ZO ČSOP Vlašim: 106-111.

Lusk S., Lusková V. \& Hanel L. (2010): Alien species in the Czech Republic and their impact on the native fish fauna. - Folia Zool. 59: 57-72.

Lusk S., Lusková V., Halačka K. \& Horák V. (2002a): Osteichthyes. In: Řehák Z., Gaisler J., Chytil J. (eds): Vertebrates of the Pálava Biosphere Reserve of UNESCO. - Folia Fac. Sci. Nat. Univ. Masarykianae Brunensis, Biologia 106: 29-49.

Lusk S., Lusková V., Halačka K. \& Lojkásek L. (2000): Změny v druhové skladbě ichtyofauny na území České republiky po roce 1990. - Biodiverzita ichtyofauny ČR (III): 21-28.

Lusk S., Lusková V., Halačka K., Šlechta V. \& Šlechtová V. (2002b): Status and protection of species and intraspecific diversity of the ichthyofauna in the Czech Republic: 23-33 pp. In: Colares-Pereira M.J., Coelho M.M., Cowx I.G. (eds): Conservationof freshwater fishes: Options for the future. Fishing News Books, Blackwell Science Ltd, Oxford, 462 pp.

Lusk S., Lusková V., Hanel L., Lojkásek B. \& Hartvich P. (2011a): Červený seznam mihulí a ryb České republiky - verze 2010. - Biodiverzita ichtyofauny ČR (VIII): 68-78.

Lusk S., Lusková V. \& Hanel L. (2011b): Černý seznam nepůvodních invazivních druhů ryb České republiky. Biodiverzita ichtyofauny ČR (VIII): 79-97.

Lusk S., Májsky J., Lusková V. \& Halačka K. (2002c): Výskyt sekavčíka horského Sabanejewia balcanica (Karaman, 1922) v toku Vláry na území České republiky a Slovenska. - Biodiverzita ichtyofauny ČR (IV): 121-126.

Merta L. (2008): Vzácné druhy mihulí a ryb Olomouckého kraje. Rozššření a ochrana. Agentura ochrany př́rody a krajiny ČR, 79 pp.

MŽP (2007): Národní strategický plán pro oblast rybářství na období 2007-2013. Ministerstvo Životního prostředí ČR, 49 pp.

Plesník J. \& Cepáková E. (2005): Kategorie a kritéria IUCN - Světového svazu ochrany přírody pro červené seznamy ohrožených druhů, pp.15-35, In: Farkač J., Král D. \& Škorpík M. (eds): Červený seznam ohrožených druhů Č. republiky. Bezobratlí. Agentura ochrany př́rody a krajiny ČR, Praha, 760 pp.

Pokorná L. (2011): Nepůvodní druhy ryb ve světle zákona o ochraně přírody. - Ochrana př́rody (1): 12-13.

Mamcarz A. (2000): Decline of the Atlantic sturgeon Acipenser sturio L., 1758 in Poland: An outline of problems and prospects. - Bol. Inst. Esp. Oceanogr. 16(1-4): 191-202.

Mendel J., Lusk S., Lusková V., Koščo J., Vetešník L. \& Halačka K. (2008a): Druhová pestrost hrouzků rodů Gobio a Romanogobio na území České republiky a Slovenska. - Biodiverzita ichtyofauny ČR (VII): 17-24.

Mendel J., Lusk S., Vasil'eva E.D. et al. (2008b): Molecular phylogeny of the genus Gobio Cuvier, 1816 (Teleostei: Cyprinidae) and its contribution to taxonomy. - Molecular Phylogenetics and Evolution 47: 10611075.

Miller R.M., Rodríguez J.P., Aniskowicz-Fowler T. et al. (2007): National threatened species listing based on IUCN criteria and regional guidelines: current status and future perspectives. - Conserv Biol. 21(3):684-96.

Rodríguez J.P. (2008): National Red Lists: the largest global market for IUCN Red List Categories and Criteria. - Endang.Species Res. 6: 193-198.

Rodríguez J.P., Keith D.A., Rodríguez-Clark K.M. et al. (2015): A practical guide to the application of the IUCN Red List of Ecosystems criteria. - Phil. Trans. R. Soc. B 370: 20140003.

Slavíkova A., Pravec M., Horecký J. \& Dobrovský P. (2009): Koncepce zprůchodnění rúínní sítě ČR. MŽP, Praha, 14 pp., 9 maps.

Volaufová L. (2008): Kvalita povrchových vod v České republice. - Vesmír 87: 769-770.

Vostradovský J. \& Šmíd J. (1999): Pstruh mořský opět v Labi? - Rybářství 5: 216-218. 
Williot P., Rochard E., Desse-Berset N., Kirschbaum F. \& Gessner J. (2011): Biology and Conservation of the European Sturgeon Acipenser sturio L. 1758: The Reunion of the European and Atlantic Sturgeons. Springer Science \& Business Media, 668 pp.

\section{Aktuální míra ohrožení ryb v jednotlivých úmořích České republiky}

Vyhodnocení změn v rozširrení populací jednotlivých druhů ichtyofauny (mihule a ryby) a identifikace nepř́iznivých vlivů je nutným předpokladem ke správné volbě nápravných opatření. Říční sít' České republiky náleží ke třem úmořím (Severní moře, Baltské moře, Černé moře). Druhová skladba původní ichtyofauny a míra ohrožení některých druhů jsou v jednotlivých úmoří rozdílné (Tabulka 1). Původní ichtyofaunu České republiky tvoří 4 druhy mihulí a 55 druhů ryb. $Z$ toho pouze 1 druh mihulí a 31 druhů ryb jsou původní ve všech třech úmořích. $\mathrm{V}$ úmoří Severního moře jako původní je hodnoceno 37 druhů ryb, z toho jsou 4 druhy EX, 1 druh EW a 11 druhů (29.7\%) ohrožených. V úmoří Baltského moře z celkem hodnocených 35 druhů jsou 4 druhy EX, 1 druh EW a 8 druhů (22.8\%) ohrožených. V úmoří Černého moře ze 49 druhů jsou 4 druhy EX a 23 druhů (46.9 \%) ohrožených.

K nejvýznamnějším vlivům, které byly přičinou vymizení nebo omezení výskytu určitých druhů ryb náleží znečištění vody, úpravy koryt vodních toků, omezení možnosti záplav aluviálních území, trvalá fragmentace povodí a rozšíření invazivních druhů. Z uvedených faktorů byla pozitivní změna zaznamenána pouze ve výrazném poklesu míry znečištění vodních toků po roce 1990. Rovněž rybářství je hodnoceno jako soubor cílených biomanipulací, účelově a často jednostranně ovlivňující rybí společenstva ve prospěch druhů, které jsou objektem sportovního rybolovu.

Authors' addresses: Stanislav Lusk, Bohuslava Martinů 9, 60200 Brno, Czech Republic.

E-mail: luskst@seznam.cz

Bohumír Lojkásek, Faculty od Science, Dept. of Biology and Ecology, Univ. of Ostrava, Chittussiho 10, 71000 Ostrava-Slezská Ostrava, Czech Republic.

E-mail: bohumir.lojkasek@osu.cz

Lubomír Hanel, Faculty of Education, Department of Biology and Environ. Education, Charles University of Prague, Magdalény Rettigové 4, 11639 Praha 1, Czech Republic.

E-mail: lubomirhanel@seznam.cz

Věra Lusková, Bohuslava Martinů 9, 60200 Brno, Czech Republic.

Petr Hartvich, P.H.Fr. Ondř́íčka 12, 37011 České Budějovice, Czech Republic.

E-mail: hartvich@seznam.cz 